Preliminary Communications

\title{
Michael acceptor properties of 6-bicycloaryl substituted (R)-5,6-dihydro-2H-pyran-2-ones
}

\author{
Pınar Kasaplar ${ }^{\mathrm{a}}$, Özgür Yılmazer Çakmak ${ }^{\mathrm{c}}$, Ali Çă̆ır ${ }^{\mathrm{b}, \mathrm{c}, *}$ \\ ${ }^{a}$ Institute of Chemical Research of Catalonia, Avinguda Països Catalans, 16, E-43007 Tarragona, Spain \\ ${ }^{\mathrm{b}}$ Izmir Institute of Technology, Faculty of Science, Department of Chemistry, Urla 35430, Izmir, Turkey \\ 'Izmir Institute of Technology, Biotechnology and Bioengineering Central Research Laboratories, Urla 35430, Izmir, Turkey
}

\section{A R T I C L E I N F O}

Article history:

Received 19 April 2010

Available online 23 July 2010

\section{Keywords:}

(R)-goniothalamin

$\log P$

Cytotoxicity

Michael addition

5,6-Dihydro-2H-pyran-2-one

\begin{abstract}
A B S T R A C T
The mechanism of action for $\alpha, \beta$-unsaturated lactones can be explained by their Michael acceptor properties. They have the potential of being covalently binding inhibitors by accepting nucleophiles from target proteins. In this work, Michael addition reactions of ethanethiol with 6-bicycloaryl substituted 5,6dihydro-2H-pyran-2-ones were studied to explore the existence of such interactions. Three of the Michael addition products were isolated and tested over PC3 (human prostate cancer) and MCF-7 (human breast adenocarcinoma) cancer cell lines and no cytotoxicity was observed. It was revealed that biological activity depends on the existence of a Michael acceptor, but potency probably depends upon the 3D structure of the substituent on lactone ring. The primary chemical-quantum properties of the lactones were also calculated using the Spartan'08 computer program.
\end{abstract}

(c) 2010 Elsevier Inc. All rights reserved.
Many biologically active natural compounds possess $\alpha, \beta$-unsaturated $\delta$-lactones in their structures as a unique pharmacore. It is believed that, because of their ability to behave as a Michael acceptor, these unsaturated carbonyls can bind themselves to the nucleophilic part of a target enzyme [1]. It is very difficult to explain why this class of molecules directly reacts with a specific target while there are potentially many other target nucleophiles within the same cell. Goniothalamin (from Cryptocarya caloneura) [2], cytostatin (from Streptomyces sp. MJ654-NF4) [3], and fostriecin (from Streptomyces pulveraceus) [4] are examples showing cytotoxicity against human cancer cell lines at submicromolar concentrations.

Recently in our laboratory, goniothalamin (1) has been shown as a potential lead molecule for the synthesis of eight new bicycloaryl substituted $\alpha, \beta$-unsaturated- $\delta$-lactones and their cytotoxic properties against PC3 and MCF-7 tumor cell lines have been evaluated [5]. Six of the most cytotoxic of these are represented in Fig. 1. Interestingly, compounds $\mathbf{1 - 5}$ were cytotoxic at submicromolar concentrations while compound $\mathbf{7}$ showed cytotoxicity at the nanomolar range whereas compound $\mathbf{6}$ was the most cytotoxic having an $\mathrm{IC}_{50}$ of $50 \mathrm{nM}$ for PC3 cell lines [5].

Here, computer modeling software was used to help understand why, out of compounds 1-7, compounds 6 and $\mathbf{7}$ showed enhanced cytotoxicity. Michael addition reactions of ethanethiol to com-

\footnotetext{
* Corresponding author at: İzmir Institute of Technology, Faculty of Science, Department of Chemistry, Urla 35430, İzmir, Turkey. Fax: +90 2327507509.

E-mail address: alicagir@iyte.edu.tr (A. Çağır).
}

pounds 1-7 were studied to explore their relative reactivities with sulfhydryl based nucleophiles in biological systems.

Energy minimization of compounds 1-7 has been calculated using the Spartan'08 [6] software via the semi-empirical AM1 method. The primary chemical-quantum properties of lactones were also calculated by the same method. Results of the calculations are summarized in Table 1.

Compounds 1-7 were prepared as previously reported literature [5]. To carry out Michael addition reactions simply, 5-10 mg of compounds (1-7) was dissolved in DMSO- $\mathrm{d}_{6}$ and then a blank ${ }^{1} \mathrm{H}$ NMR was acquired. Then one equivalent of ethanethiol was added with a syringe and mixed well. Ten minutes after the addition of ethanethiol, a subsequent ${ }^{1} \mathrm{H}$ NMR spectrum was taken. If the reactions were not complete within $10 \mathrm{~min}$, then reactions were monitored by taking an ${ }^{1} \mathrm{H}$ NMR spectrum taken at continued appropriate intervals. The rate of the reactions were evaluated by the disappearance of signals belonging to protons attached to the $\alpha, \beta$-unsaturated carbons as well as the signals from the appearance of new diastereomeric saturated protons.

To determine the cytotoxicity of the compounds, MTT assay were performed under the same condition reported in literature at $0.1,0.5,1,10$, and $50 \mu \mathrm{M}$ concentrations [5].

The Corey-Pauling-Koltun (CPK) space-filling model volume and area for compounds $\mathbf{6}$ and $\mathbf{7}$ were approximately 20 units $\left(\AA^{3}\right.$ and $\AA^{2}$ ) higher than for compounds 1-5. Log $P$ values (measurement of permeability of the cell membrane) for compounds 6 and $\mathbf{7}$ were the same (3.87), but higher than the $\log P$ values for compounds 2 and 4 (3.38). $\log P$ values for the quinoline derivatives 


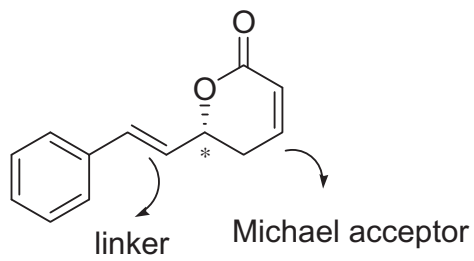<smiles>O=C1C=CC[C@H](c2ccc3ccccc3c2)O1</smiles>

2<smiles>O=C1C=CCC(c2ccnc3ccccc23)O1</smiles>

5<smiles>O=C1C=CC[C@H](c2cnc3ccccc3c2)O1</smiles>

3<smiles>Cc1ccc2ccccc2c1C1CC=CC(=O)O1</smiles>

6<smiles>O=C1C=CCC(c2cccc3ccccc23)O1</smiles>

4<smiles>Cc1ccc(C2CC=CC(=O)O2)c2ccccc12</smiles>

7

Fig. 1. Structure of goniothalamin (1) and 6-bicycloaryl substituted (R)-5,6-dihydro-2H-pyran-2-ones (2-7).

Table 1

Calculated main chemical-quantum properties of compounds 1-7.

\begin{tabular}{lllll}
\hline Comp. & CPK area $\left(\AA^{2}\right)$ & CPK volume $\left(\AA^{3}\right)$ & PSA $\left(\AA^{2}\right)$ & $\begin{array}{l}\text { Log } P(\text { Crippen } \\
\text { model })\end{array}$ \\
\hline $\mathbf{1}$ & 236.06 & 218.33 & 21.82 & 2.90 \\
$\mathbf{2}$ & 245.15 & 236.70 & 21.32 & 3.38 \\
$\mathbf{3}$ & 240.62 & 230.47 & 28.56 & 2.47 \\
$\mathbf{4}$ & 241.96 & 236.11 & 20.68 & 3.38 \\
$\mathbf{5}$ & 237.42 & 229.96 & 27.82 & 2.47 \\
$\mathbf{6}$ & 262.23 & 254.40 & 19.65 & 3.87 \\
$\mathbf{7}$ & 259.85 & 253.97 & 20.87 & 3.87 \\
\hline
\end{tabular}

(3 and 5) and goniothalamin (1) were 2.47 and 2.10, respectively. Plotting the known $\mathrm{IC}_{50}$ values for the compounds [5] as a function of lipophilicity, it is seen that in general, as lipophilicity increases, cytotoxicity increases for compounds 1-7 (Fig. 2). It seems plausible that 6-bicycloaryl substituted 5,6-dihydro-2H-pyran-2-ones, having higher CPK volumes, areas, and lipophilicities, demonstrate higher cytotoxicity.

There is not any other similar biologically active molecule, which can be pooled in this QSAR study or can be discussed. Only goniothalamin derivatives can be considered as structurally relevant molecules. Interestingly, Zhou and his coworkers had synthesized 14 goniothalamin derivatives and evaluated their cytotoxicities [7]. In the same work the authors reported that derivatives of goniothalamin, having $\log P$ values between +4.4 and +4.7 , possessed good activities ( $\mathrm{IC}_{50}$ was $0.18-0.68 \mu \mathrm{g} / \mathrm{mL}$ ). Their result is completely parallel to our findings.

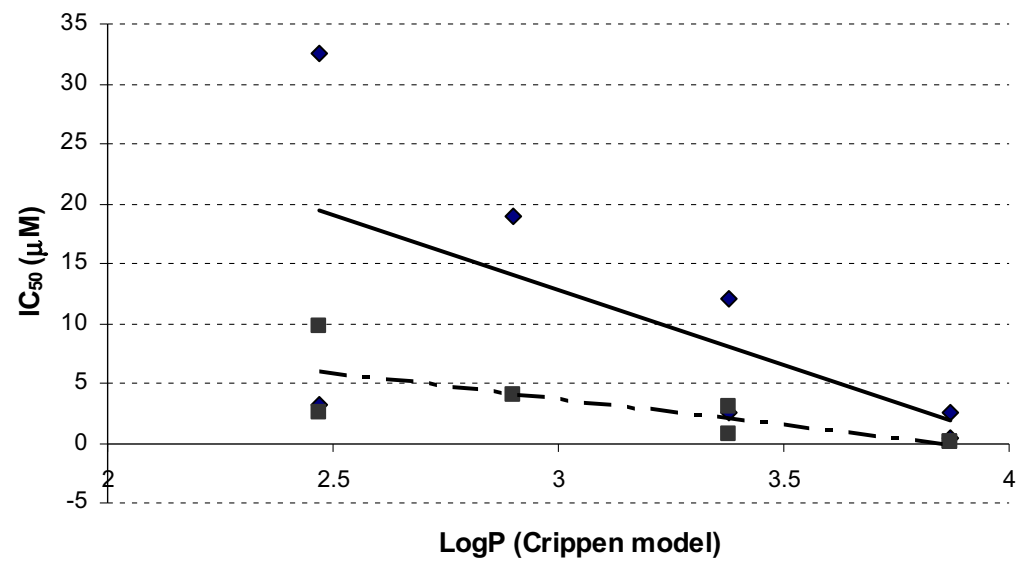

- MCF-7 $\square$ PC-3 L Linear (MCF-7) - - - Linear (PC-3)

Fig. 2. Relationship between $\log P$ (Crippen model) and $\mathrm{IC}_{50}$ values for the cytotoxicity of compounds 1-7 against MCF-7 and PC3 cancer cell lines. 
<smiles>O=C1C=CC[C@@H]([18O])O1</smiles>

$1-5,7$<smiles>CCS[C@H]1CC(=O)O[C@@H]([AlH2])C1</smiles>

$8-13$
Fig. 3. Michael addition reactions of ethanethiol with goniothalamin (1) and 6bicycloaryl substituted (R)-5,6-dihydro-2H-pyran-2-ones (2-7).

In earlier works, kinetic studies of the Michael addition reactions of ethanethiol to biologically active $\alpha, \beta$-unsaturated carbonyls were used to understand the relative reactivity of compounds with similar thiol-based nucleophiles in biological systems, sometimes also being accepted as the actual source of biological activity [8-12]. Similarly reactions of ethanethiol with (R)-goniothalamin (1) and 6-bicycloaryl substituted 5,6-dihydro-2H-pyran-2-ones (2-7) can be useful to rationalize their relative cytotoxicity and to find any explanation for the greater cytotoxicity of 1-naphthyl substituted 5,6-dihydro-2H-pyran-2-ones (Fig. 3).
${ }^{1} \mathrm{H}$ NMR chemical shifts, multiplicities, and coupling constants of the lactones subunit for compounds 1-7 are listed in Table 2. For compounds 2-7, signals belonging to protons attached to the $\beta$-carbon shifted downfield to a greater extent than that those associated with $(\mathrm{R})$-goniothalamin by $0.1 \mathrm{ppm}$. It is expected that $\beta$-carbons of lactones 2-7 should be more electron deficient than the $\beta$-carbon of goniothalamin allowing them to react faster.

When $(R)$-goniothalamin (1) was reacted with 0.75 equivalent of ethanethiol, the intensity of the signals for the $\alpha$ and $\beta$-carbons, at 6.01 and $7.08 \mathrm{ppm}$ respectively, diminished after $10 \mathrm{~min}$. Additionally, the peak for the benzylic proton at $5.15 \mathrm{ppm}$ was getting smaller while two new multiplets appeared at 5.24 and $5.04 \mathrm{ppm}$, indicating the formation of two unknown diastereomers in the ratio $1: 4$. When the amount of ethanethiol was increased to two equivalents, the peaks for the $\alpha$ and $\beta$ protons completely disappeared. At the same time, formation of two unknown diastereomers was completed at a ratio of 1:5. The reaction between goniothalamin and excess nucleophile was quite fast, with the entire reaction being completed in less than $10 \mathrm{~min}$ (Fig. 4).

Similarly, reactions between ethanethiol and pyranones (2-5 and $\mathbf{6}$ ) were completed in less than $10 \mathrm{~min}$. In brief, peaks belong-

Table 2

${ }^{1} \mathrm{H}$ NMR chemical shift for lactones in compounds 1-7.

\begin{tabular}{|c|c|c|c|c|c|c|c|c|}
\hline \multirow[t]{2}{*}{ Comp. } & \multicolumn{2}{|l|}{$\mathrm{CH}$} & \multicolumn{2}{|l|}{$\mathrm{CH}_{2}$} & \multicolumn{2}{|l|}{$\alpha \mathrm{CH}$} & \multicolumn{2}{|l|}{$\beta \mathrm{CH}$} \\
\hline & $\delta^{\mathrm{a}}(\mathrm{ppm})$ & Multiplets $(\mathrm{J}$ in $\mathrm{Hz})$ & $\delta^{\mathrm{a}}(\mathrm{ppm})$ & Multiplets $(\mathrm{J}$ in $\mathrm{Hz})$ & $\delta^{\mathrm{a}}(\mathrm{ppm})$ & Multiplets ( $\mathrm{J}$ in $\mathrm{Hz}$ ) & $\delta^{\mathrm{a}}(\mathrm{ppm})$ & Multiplets $(\mathrm{J}$ in $\mathrm{Hz})$ \\
\hline 1 & 5.15 & $\mathrm{dt}(10.2,5.0,5.0)$ & 2.54 & $\mathrm{~m}$ & 6.01 & dd $(9.9,1.2)$ & 7.08 & $\mathrm{~m}$ \\
\hline 2 & 5.71 & dd $(8.0,8.0)$ & 2.76 & $\mathrm{~m}$ & 6.10 & $\mathrm{~d}(9.74)$ & 7.17 & $\mathrm{~m}$ \\
\hline 3 & 5.85 & dd $(9.3,6.7)$ & 2.87 & $\mathrm{~m}$ & 6.15 & dt $(9.7,1.7,1.7)$ & 7.23 & ddd $(9,7,5.6,3.6)$ \\
\hline 4 & 6.33 & dd $(11.4,4.6)$ & 2.84 & $\mathrm{~m}$ & 6.14 & ddd $(9.7,2.5,1.0)$ & 7.21 & ddd $(9.7,5.8,2.6)$ \\
\hline 5 & 6.43 & dd $(11.8,4.2)$ & 2.78 , and 2.91 & $\mathrm{~m}$, and $\mathrm{m}$ & 6.18 & $\mathrm{~m}$ & 7.22 & ddd $(9.7,6.0,2.5)$ \\
\hline 6 & 6.34 & dd $(13.3,4.5)$ & 3.07, and 2.66 & $\mathrm{~m}$, and ddd $(19,8,12.2,6.8)$ & 6.17 & dd $(9.9,1.8)$ & 7.22 & ddd $(9.8,6.2,1.9)$ \\
\hline 7 & 6.29 & dd $(11.7,4.3)$ & 2.82 & $\mathrm{~m}$ & 6.13 & ddd $(9.7,2.5,0.8)$ & 7.21 & ddd $(9.7,5.9,2.5)$ \\
\hline
\end{tabular}

Water peak was used as reference at $3.33 \mathrm{ppm}$.

a NMRs were recorded at $400 \mathrm{MHz}$ using Varian NMR spectrophotometer and processed by MestreNOVA in DMSO- $\mathrm{d}_{6}$.

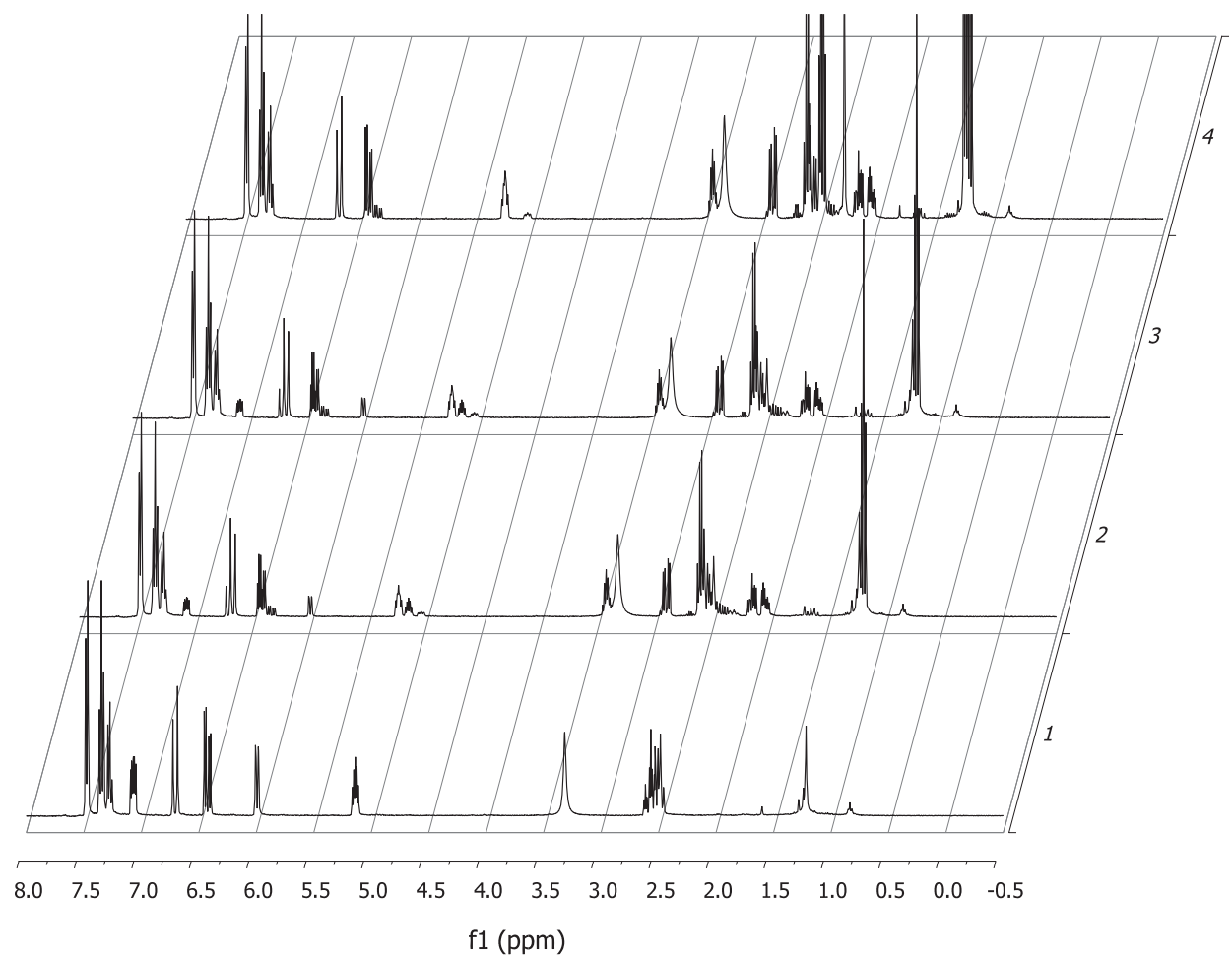

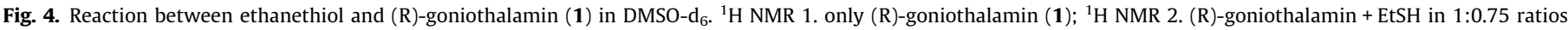
(10 min); ${ }^{1} \mathrm{H}$ NMR 3. (R)-goniothalamin + EtSH in 1:0.75 ratios (20 min); ${ }^{1} \mathrm{H}$ NMR 4. (R)-goniothalamin + EtSH in $1: 2$ ratios (10 min). 


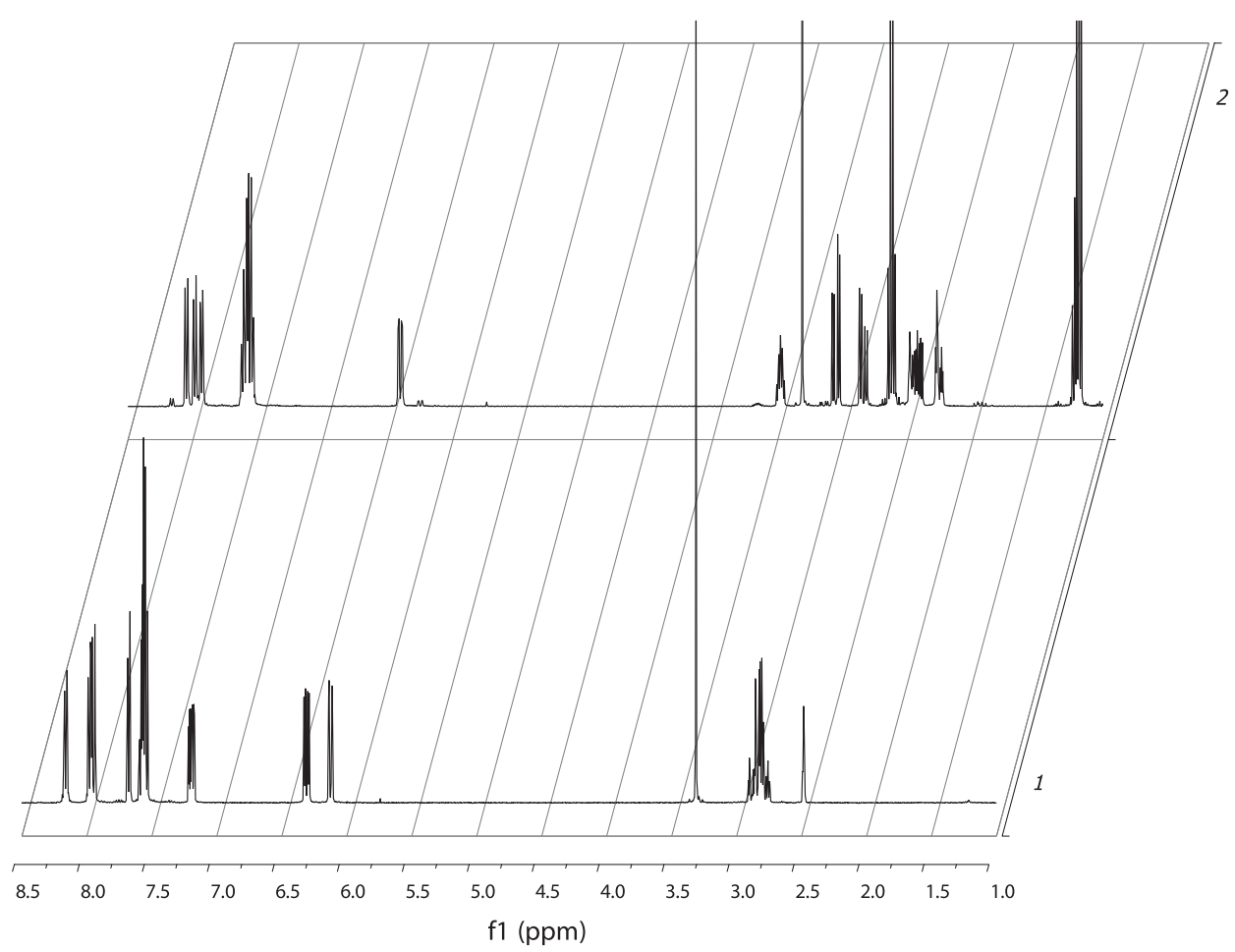

Fig. 5. Reaction between ethanethiol and compound 4 in DMSO- $\mathrm{d}_{6} .{ }^{1} \mathrm{H}$ NMR (1) only compound $\mathbf{4}$; ${ }^{1} \mathrm{H}$ NMR (2) compound $4+$ EtSH in $1: 1.3$ ratios (10 min).

ing to the $\alpha$ and $\beta$ protons disappeared completely and the peaks for the benzylic protons shifted downfield (Table 2). Formation of new doublets of doublets were observed at 5.78 (10.5, and $3.6 \mathrm{~Hz}) ; 5.94(10.8$, and $3.7 \mathrm{~Hz}) ; 6.42(10.4$, and $3.4 \mathrm{~Hz}) ; 6.50$ (9.0, and $4.7 \mathrm{~Hz})$; and $6.39(10.4$, and $3.3 \mathrm{~Hz}) \mathrm{ppm}$ for the benzylic protons of products 9-13. The ${ }^{1} \mathrm{H}$ NMR spectrum, showing the reaction between ethanethiol and compound 4, are given in Fig. 5 as an example. It seems that there is no difference at all between the kinetics of Michael addition reactions, so enhanced cytotoxicity of 1-naphthyl substituted 5,6-dihydro-2H-pyran-2-ones may not be explained by kinetic issues.

Moreover, ethanethiol addition products for compounds 1, 2, and $\mathbf{4}$ were purified on a silica gel column and tested against PC3 and MCF-7 cancer cell lines to evaluate the importance of unsaturated lactones for biological activity. No cytotoxicity was seen when the MTT assay [5] was applied at $0.1,0.5,1,10$, and $50 \mu \mathrm{M}$. Lack of cytotoxicity can be explained either by the steric hindrance of the ethanethiol component or the lack of a Michael acceptor on the lactone rings of tested compounds. Hence, these results implies that higher $\log P$ values and existence of 5,6-dihydro-2H-pyran-2one subunit is quite crucial for the biological activity of tested compounds 1-7.

In literature it is believed that the Michael addition of the nucleophilic site of proteins to the $\beta$-carbons of $\alpha, \beta$-unsaturated carbonyl is responsible element for the biological activity. Although it is also true for the derivatives reported in here, potencies of those are not directly related with the kinetics of Michael addition reaction. We believe that $\log P$ values and three dimensional structures of the substituents are as much important as Michael acceptor properties of compounds 1-7.

\section{Acknowledgments}

We thank the Biotechnology and Bioengineering Central Research Laboratories at the Izmir Institute of Technology for their help with the MTT assays of the isolated products. We are also grateful to Mrs. Işın Özçelik and Dr. Ritchie Eanes for their kind help with the NMR experiments and manuscript proofreading, respectively. This work was supported by TÜBITAK-TBAG Research Grant $105 T 429$ as awarded by The Scientific and Technological Research Council of Turkey.

\section{Appendix A. Supplementary data}

Supplementary data associated with this article can be found, in the online version, at doi:10.1016/j.bioorg.2010.06.005.

\section{References}

[1] J.M. Campagne, G. Broustal, V. Boucard, Eur. J. Org. Chem. (2007) 225 (and references thereof)

[2] J.R. Hlubucek, A.V. Robertson, Aust. J. Chem. 20 (1967) 2199.

[3] M. Amemiya, M. Ueno, M. Osono, T. Masuda, N. Kinoshita, C. Nishida, M. Hamada, M. Ishizuka, T. Takeuchi, J. Antibiot. 47 (1994) 536.

[4] (a) J.B. Tunac, B.D. Graham, W.E. Dobson, J. Antibiot. 36 (1983) 1595; (b) S.S. Stampwala, R.H. Bunge, T.R. Hurley, N.E. Willmer, A.J. Brankiewicz, C.E. Steinman, T.A. Smitka, J.C. French, J. Antibiot. 36 (1983) 1601.

[5] P. Kasaplar, O. Yılmazer, A. Çagır, Bioorg. Med. Chem. 17 (2009) 311

[6] Y. Shao, L.F. Molnar, Y. Jung, J. Kussmann, C. Ochsenfeld, S.T. Brown, A.T.B. Gilbert, L.V. Slipchenko, S.V. Levchenko, D.P. O'Neill, R.A. DiStasio Jr, R.C. Lochan, T. Wang, G.J.O. Beran, N.A. Besley, J.M. Herbert, C.Y. Lin, T. Van Voorhis, S.H. Chien, A. Sodt, R.P. Steele, V.A. Rassolov, P.E. Maslen, P.P. Korambath, R.D. Adamson, B. Austin, J. Baker, E.F.C. Byrd, H. Dachsel, R.J. Doerksen, A. Dreuw, B.D. Dunietz, A.D. Dutoi, T.R. Furlani, S.R. Gwaltney, A. Heyden, S. Hirata, C.-P. Hsu, G. Kedziora, R.Z. Khalliulin, P. Klunzinger, A.M. Lee, M.S. Lee, W.Z. Liang, I. Lotan, N. Nair, B. Peters, E.I. Proynov, P.A. Pieniazek, Y.M. Rhee, J. Ritchie, E. Rosta, C.D. Sherrill, A.C. Simmonett, J.E. Subotnik, H.L. Woodcock III, W. Zhang, A.T. Bell, A.K. Chakraborty, D.M. Chipman, F.J. Keil, A. Warshel, W.J. Hehre, H.F. Schaefer, J. Kong, A.I. Krylov, P.M.W. Gill, M. Head-Gordon, Phys. Chem. Chem. Phys. 8 (2006) 3172 (Spartan'08 has been obtained from Wavefunction, Inc. Irvine, CA).

[7] F.S. Zhou, W.D. Tang, Q. Mu, G.X. Yang, Y. Wang, G.L. Liang, L.G. Lou, Chem. Pharm. Bull. 53 (2005) 1387.

[8] B. Shi, M.F. Greaney, Chem. Commun. (2005) 886

[9] J.-S. Kong, S. Venkatraman, K. Furness, S. Nimkar, T. Shepherd, Q.M. Wang, J. Aub, R.P.J. Hanzlik, Med. Chem. 41 (1998) 2579.

[10] C.M. Cabello, W.B. Bair III, S.D. Lamore, S. Ley, A.S. Bause, S. Azimian, G.T. Wondrak, Free Radical Biol. Med. 46 (2009) 220.

[11] T.W. Schultz, J.W. Yarbrough, R.S. Hunter, A.O. Aptula, Chem. Res. Toxicol. 20 (2007) 1359.

[12] M.W. Amolins, L.B. Peterson, B.S.J. Blagg, Bioorg. Med. Chem. 17 (2009) 360. 